\title{
Operation of Ideology in Ken Kesey's One Flew over the Cuckoo's Nest
}

\author{
Sima Farshid (Corresponding author) \\ Assistant Professor, Islamic Azad University, Karaj Branch \\ Moazen blvd., Karaj, Alborz, Iran \\ Shima Lotfi \\ MA-holder, Islamic Azad University, Karaj Branch
}

Received: $12-08-2013$

Accepted: 28-09- 2013

Published: 10-01- 2014

doi:10.7575/aiac.ijclts.v.2n.1p.17

URL: http://dx.doi.org/10.7575/aiac.ijclts.v.2n.1p.17

\begin{abstract}
Considering Louis Althusser's inquiries into the function of ideology in sustaining power, the writers of this article discuss the operation of ideological and repressive apparatuses in the asylum Ken Kesey portrays in One Flew over the Cuckoo's Nest (1962). The novel recounts the story of a group of people contained in an institution that is supposed to treat their allegedly mental problems, whereas under the facade of psychiatric treatment lies a ruthless controlling system whose major purpose is to turn the inmates into obedient, submissive "subjects". The agents of the institution preserve the patients' docility through strict rules besides the so-called mental therapy that actually results in more confusion in inmates who consequently lose their self-consciousness and self-confidence. But since every ideological system, besides inducing docile "subjects," raises a sort of resistance among them, gradually resisting forces are formed in the asylum of the novel by the coming of a new inmate who defies the dominant ideology of the institution. By his jovial, life-affirming ideology, he breathes new life into others, makes them think and believe in themselves and trust each other, and thereby acts as a source of inspiration for several inmates, specially the Indian American narrator of the novel that subsequently challenges his schizophrenia, and finally, when his friend is shocked by electrical devices as the result of which he totally loses his consciousness, smashes the control panel of the ward to escape from that penitentiary.
\end{abstract}

Keywords: ideology, ISA, RSA, interpellation, symptomatic reading

\section{Introduction}

Presenting an Altusserian reading of Ken Kesey's One Flew over the Cuckoo's Nest (1962), this article deals with the suppressive operation of ideology as portrayed in the asylum of Kesey's novel. Thus the main focus of our attention is to expose how the text divulges the process of "subject formation" in that institution through the functioning of what Altusser calls Repressive State Apparatuses (RSAs) and Ideological State Apparatuses (ISAs). The characters of Kesey's novel are seemingly treated in that asylum to regain their mental health, whereas they are actually entangled in the web of ideological and repressive forces whose function is to maintain the hegemony of the supervisors of that institution. Nonetheless after a while a resisting force appears in the institution by the arrival of a new inmate who urges others to defy the strict rules of the authorities. Although he is eventually almost killed by electrical shock, he inspires several inmates to stand against authorities, the most notable of whom is the Indian American narrator of the novel.

The American writer Kenneth Elton Kesey (1935-2007) is best known for his famous novel One Flew over the Cuckoo's Nest whose cinematic adaptation won five Academy Awards in 1975. He was a non-conformist writer in line with the "beat culture" of the 1960s whose motto was a return to nature against the industrialization of the time. Besides he had a considerable role in the rise of the "counter-culture" movement which strongly resisted the abuse of psychiatric treatment of the time. Kesey's familial background is also endowed with perseverance and "self-reliance," along with an intimate relationship with nature - the attributes also discernible in One Flew over the Cuckoo's Nest. His works disclose his increasing awareness of the functioning of the prevailing ideology that his rebellious spirit permanently refuted and defied.

One Flew over the Cuckoo's Nest has drawn the attention of several critics who have mostly dealt with the noncompliant nature of the novel, yet none of them has offered an Althusserian reading of it. Stephen L. Tanner considers Kesey a rebellious writer, and refers to the novel as a semi-autobiographical work in which Kesey's familial background "registers clearly - in the strength, self-reliance -, and competitiveness of the hero" $(1973,164)$. He also argues that the novel "evokes a pleasure of recognition; readers are confirmed in a knowledge of their society that they scarcely knew they possessed" $(1973,161)$. The reading Fred Madden offers of the novel suggests that Kesey depicts "any social pressure can 'condition' the individual and destroy his freedom of choices," thus he draws attention to Kesey's particular emphasis on "individuality," and affirms that "the conflict between individual choice and the social pressure is crucial to the novel" $(1986,112)$. Although they heed Kesey's depiction of psychological, social pressures on individuals, they do not tackle the operation of ideology in exerting those pressures. 


\section{Althusserian Marxism}

The French Marxist thinker Louis Althusser (1918-1990) with his new standpoint on Marxism gives priority to the role of ideology in upholding the hegemony of the ruling class. Asserting that all of us are "born into ideology," he holds that we cannot escape this set of images, ideas and beliefs in the web of which we live and act. The dominant ideology of every society, Althusser argues, is engendered by the intellectuals who serve the ruling class. They make an "imaginary relationship of individuals to their real conditions of existence" $(1971,162)$, and insert it in individuals' unconsciousness, so that the ruling class can control and exploit them. He also holds that those intellectuals construct a system of monitoring apparatuses which interpellate individuals' mind and turn them into obedient "subjects" whose social roles are decided for them by the ruling "Subject," whereas the "subjects" assume themselves to be free to form and determine their own life.

The main function of ideology in Althusser's eyes is to control subjects through cultural institutions he calls ISAs (Ideological State Apparatuses) without which no state can maintain its power, as he states here: "no class can hold state power over a long period without at the same time exercising its hegemony over and in the State Ideological Apparatuses" (1971, 146). Along with ISAs, he argues, RSAs (Repressive State Apparatuses) are needed to sustain the hegemony of the ruling class. The most significant RSAs are "the Government, the Army, and the Police" which constitute an "organized whole" and function "by violence" $(1971,145)$. Nevertheless along with the exercise of the dominant ideology by ISAs, Althusser holds, there are "different ideological tendencies" in every given society that imply a kind of resistance among subjects, this way the "ruling class lives its own ideology, just as the exploited class" (1990, 30), although he never ignores the fact that the resistance of the subjects is embedded in the very system induced by the ideology of the Subject.

Following the above-mentioned ideas, Althusser's student and collaborator Pierre Macherey (b. 1938) has contended that a literary work presents not only the ideology out of which it is produced, but also the critique of that ideology. $\mathrm{He}$ argues that even though literary works are "pervaded by ideology" (qtd. Bertens 2001, 92), they do not "simply contain the meaning their authors intended to express in them, as a nutshell contains a nut, but are in fact made up of many different and conflicting meanings" (qtd. Ferretter 2006, 60). Macherey's proposed method for reading literary works is symptomatic reading that he employs to detect two sorts of meaning in a text: the explicit one that comes out of the author's conscious intention, and the implicit one of which the author is not conscious. Therefore symptomatic reading focuses on "the gaps, contradictions and logical flaws in the text" (Ferretter 2006, 57) which unveil the points the text does not say and "represses rather than expresses" (qtd. Bertens 2001, 92).

\section{Operation of ISA and RSA in One Flew over the Cuckoo's Nest}

One Flew over the Cuckoo's Nest (1962) narrates the story of some people who apparently suffer from mental problems and are thus treated in an asylum whose frontage of mental-health care conceals a callous controlling system whose major plan is to induce and sustain submissiveness among patients rather than solving their problems. The agents of the institution maintain patients' tameness and obedience through strict rules and physical rigidity besides the so-called mental therapy that results in more confusion for patients who cannot hence any longer think independently or solve their problems.

The most abhorrent agent of the institution, named "combine" by the narrator, is Nurse Ratched who is called the Big Nurse - reminding the reader of Orwell's Big Brother. She is an inflexible middle-aged woman who sees the world through the lenses of discipline and order and utilizes all possible means to keep the ward under her entire control. Noteworthy among her features are her "precise, automatic gesture" and "smooth, calculated, and precision-made" face $(1962,5)$. She spends most of the day in a "glass station" (27) to observe patients" activities and take notes about them, and her machine-like conduct, indifferent look, and hardnosed attitude toward patients and staff generate fear and anxiety in the ward. She has divided the patients into two groups, and makes them "spy on each other" (15) to keep them separated and distrustful of each other. She looks like "Army nurses" (278) to the narrator who sees her in his mind's eye as a machine rather than a human being, as he states here: "her painted smile twists, stretches to an open snarl, and she blows up bigger and bigger, big as a tractor, so big I can smell the machinery inside the way you smile a motor pulling too big a loud" (5).

Considering Althusser's theories, we see that the Big Nurse employs different Ideological and Repressive Apparatuses to keep her power unbeatable. Her foremost strategy is to maintain her façade of sane helpfulness for insane people. She never rejects an idea directly, but by a special choice of words persuades the patients to believe that their needs are in the center of her concerns, and thereby turns them into submissive "subjects." One of her methods to control them and smash their individualities is to "render [them] impotent," as Sullivan has observed $(1975,16)$, the result of which is their total dependence on her who thus seems to be "a bull-cutter" $(1962,60)$.

One of the rules Nurse Ratched has set for the patients to maintain her hegemony over them is that a "good boy" is the one who exactly follows her orders, and to force them do so, she draws on their fears of mothers or wives. One instance is the case of Billy Bibbit and his mother who is a close friend of the nurse and treats her 31-year-old son as a little boy. Whenever Billy does something against the Big Nurse's rules, she threatens him to tell on him to his mother. Harding's wife is another helper of hers, as she deems her husband a clumsy man, deprived of manhood and incapable of satisfying her sexual needs. Resorting to such degrading ideas about sons or husbands, or in Althusser's words Family Ideological Apparatus, is thus a vehement means in the hands of the Big Nurse to sustain her power. Therefore the picture Kesey portrays of women on the whole is a misogynist one that exposes them as emasculating figures that 
victimize men and turn them into weak ideological "subjects," as Harding affirms himself: "we are victims of a matriarchy here" $(1962,67)$.

"Psychiatric Therapy" is the most effective ideological apparatus of the Big Nurse to keep the patients under control, since they are totally convinced that it helps them regain their mental health, whereas it is actually of no help to them and makes them more confused and incapable of thinking and realizing how it "dehumanizes" them. With regard to Althusser's theory of political interpellation, we see patients as ignorant "subjects" that submissively obey the "Subject," one of whose ideological apparatuses is Dr. Spivey who portrays a "democratic" picture of the ward as a place where everything is managed according to the patients' benefits and desires whenever a new patient is brought to the ward, and in so doing practices psychological interpellation. Another way to sustain patients' submissiveness is to keep them ignorant of the world outside, with the excuse that "the world news must not be therapeutic" (1962, 79), so that they suppose the ward staffs are actually helping them to regain their mental health, as one of them states: "The staff desires our cure as much as we do. They aren't monsters" $(1962,39)$.

Althusser holds that power-holders maintain their authority not only through ideological apparatuses, but also by the force and violence of repressive apparatuses. The most effective repressive apparatus in the hands of the Big Nurse are "Black Aides," "Shock Therapy" and "Lobotomy" through which she suppresses any uproar in the ward. Three robust black attendants are her aides to keep the patients hushed and subdued, and as long as the patients behave according to her will, they are safe from shock treatment, but when they break her rules, they are doomed to undergo "Shock Therapy" and "Lobotomy". As the result of being shocked by electrical devices, the punished patient more or less loses his consciousness, as Harding affirms: "You pay for the service with brain cells instead of money" (1962, 189), and thus becomes a sign of admonition for other inmates who consequently do not dare stand against the Big Nurse's rules. Regarding these punishments to subdue patients, Terrence Martin confirms that "the Shock Therapy machine turns men docile and lobotomy converts even the most unruly into Fully Adjusted Products. These are weapons of terror, dedicated to the proposition that the best man is a good boy" $(1973,6)$ - exactly what the Big Mother expects them to be!

\section{Resistance against Dominant Ideology}

Althusser contends that despite the operation of ideological and repressive apparatuses in every given society, subjugated people gradually form their own ideology against that of the governing people. In One Flew over the Cuckoo's Nest, the resisting force of the inmates against the hegemony of the Big Nurse is invoked by Randle Patrick McMurphy who confronts the ideological apparatus of the institution, and hoists a kind of awakening in others, thereby acts as the source of inspiration for the final mutinous act of Chief Bromden the Indian American narrator of the novel. Although McMurphy is introduced as a swindler when he enters the ward, he is later depicted as a hero who vehemently challenges the meticulously constructed controlling system of the institution. A short time after his arrival, he breathes new life into the dead body of the asylum by his strong sense of humor and comic exaggeration, and activates the patients to change their way of life, believe in themselves and trust each other, thereby acts as a source of inspiration for several inmates, specially the narrator.

His colloquial, untailored way of speaking and loud laughs are the first acts of rebellion in the strictly run ward. The narrator describes Randle's laugh this way: “it's free and loud and it comes out of his wide grinning mouth and spreads in rings bigger and bigger till it's lapping against the walls all over the ward," and realizes "all of a sudden [that] it's the first laugh I have heard in years" $(1962,12)$. Besides his gestures and speaking manner, McMurphy's appearance and physical attributes signify his sharp difference from other inmates. The writer puts much emphasis on his manly behavior and "hard masculinity" - the features other patients have lost, and exposes how he invokes the sense of life and lost "manhood" in them. His loud voice, songs, interesting stories, and above all his "sociable free spirit" so much appeals to the inmates that they gradually look at him as a role model.

McMurphy makes use of every situation to release the inmates from the predicament of their machine-like lives, and in so doing generates a kind of awakening in the patients who begin to regain their "self-consciousness," and hence "become able and willing to struggle for life," as Hicks has also suggested $(1981,77)$. Gradually several inmates dare to announce their opinion and protest against their disagreeable situation. Randle molds a "community" in the ward whose members do not spy on each other, consequently commences the true psychiatric therapy as the result of which the patients go through a sort of mental healing; they start to think, believe in themselves and trust others. They are so changed after a while that when the Big Nurse decides to "send McMurphy to Disturbed," all inmates protest; "all twenty of them, raising not just for watching TV, but against the Big Nurse, against her trying to send McMurphy to Disturbed, against the way she's talked and acted and beat them down for years" $(1962,140)$.

More than any other patient, Chief Bromden the narrator of the story is affected by McMurphy. The Indian American Chief who is the eldest inmate in the ward pretends to be deaf and dumb to save himself from the terrifying disciplines of the power structure enforced on other patients. Besides mortifying things done to all inmates, the Chief is also humiliated due to the dominant racist ideology which ignores and belittles him. He tells the reader: "it wasn't me that started acting deaf, it was people that first started acting like I was too dumb to hear or see or say anything at all" (1962, 210). The ward and its attendants seem to him like "electronic machines" that crush humanity. He suffers from a "schizophrenic mind," hence relates the story through his fragmented memories, nightmares and hallucinations. He also envisages himself to be surrounded by a dense fog, and every time the Big Nurse treats them more severely, he retreats more into the imaginary fog which acts as his defense mechanism against the terrifying world of ward; it is a kind of refuge for him; the thicker it becomes, the safer he feels. 
McMurphy reminds the Chief of his father, because his life-affirming ideology gives meaning to the Chief's seemingly futile life, and hence strikes a chord of childhood in his mind, as he affirms here: "McMurphy was teaching me. I was feeling better than I'd remember feeling since I was a kid, when everything was good and the land was still singing kid's poetry to me" $(1962,256)$. Their handshaking in the first visit seems to transmit a particular sense of power to him; "he was transmitting his own blood into it. It rang with blood and power" (25). No longer does the imaginary fog surround him and no more is the story related in fragmented memories. His mind becomes lucid and can confront the present and remember the past clearly to find out "the source of his pain and paralysis," as Hicks has also pointed out (1981, 76). Feeling sound in the presence of McMurphy, the Chief gains enough courage to reveal his secret to him, and starts speaking: "I realized what I was doing, I told him Thank you" (1962, 217). As the effect of McMurphy's "teaching," the Chief gets aware of his submissiveness; starts to stand against disciplines, and suffers more than anyone else when McMurphy is sacrificed for the sake of their freedom.

McMurphy raises an insurrection he pays terribly for and cannot bring it to an end, but his uprising is not fruitless; the Chief accomplishes it at the end by his symbolic act of blowing up the control panel that symbolizes the machinery that has dehumanized them; "The glass splashed out in the moon, like bright cold water baptizing the sleeping earth" (1962, 324), and then escapes from the prison the Big Nurse has erected out of the ward. Besides he puts an end to the plantlike life of McMurphy who has become entirely unconscious after "Lobotomy," because he does not like to let the Big Nurse feel triumphant, as he says here: "she seemed to be too sure; she seemed to be waiting for one more round, and I wanted to be there in case it came off" (321).

\section{Symptomatic Reading of the Text}

Althusser's disciple and collaborator Macherey holds that a literary work must never be considered a unified whole that manifests only one ideology, because it is produced in a complicated network of social relations, and hence embodies different ideologies, therefore to regard it as the outcome of just one ideology is to ignore the operation of those complicated relations. To achieve a deep understanding of a text and its historical origin, Macherey suggests the scrutiny of what a text "has not been able directly to express" (Ferretter 2007, 59) besides what it explicitly expresses, and calls his reading strategy the "symptomatic reading." Considering his ideas in reading One Flew over the Cuckoo's Nest, we can say that there exists an "unwritten" text besides the written one which is not discernible in the first glimpse, but can be discovered through a symptomatic reading of the novel.

That "unwritten" text is gradually revealed to us through Chief Bromden's narration of the attitude of other inmates toward McMurphy. As a narrator that conveys the writer's voice, his narration portrays a quite negative picture of Nurse Ratched who represents the authorities of the institution which in turn stand for the governing power of the society which forces people to conform to their standards of behavior. The "unwritten" text of the novel that the Chief's narration unveils, however, reveals the fact that the dominated people might be as powerful as the dominant ones to push atypical individuals to pursue their will. While reading the novel, we learn that it is not only the Big Nurse's callous conduct that runs McMurphy toward his disastrous end, but also the expectations and needs of the patients which urge him to take on the role of their savior. His attempt to unfetter them from the tyranny of the Big Nurse ultimately costs his own life.

The symptomatic reading of the novel therefore exposes how its "unwritten" text deconstructs the writer's ideology by showing that the dominated people also play their role in destroying their hero's life, and thereby reveals them to be another social pressure. Chief Bromden understands this fact at the end of novel when he says: "We couldn't help him because we were the ones making him do it. It wasn't the nurse that was forcing him, it was our need that was making him push himself slowly up from sitting .... It was us that had been making him go on for weeks" (1962, 318). By "turning rabbits into men," as Ficks properly remarks, McMurphy "negates the very terms of freedom [, seeing that he] is destroyed not by the Combine but by the united needs of the inmates - a "combine" of a very different sort" (1981, 145).

\section{Conclusion}

Althusser believes that no one can release themselves from the bondage of the dominant ideology and whatever a person does is ultimately entwined in the complicated web of ideology. Kesey's One Flew over the Cuckoo's Nest depicts the same thought in its portrayal of different reactions against the dominant ideology of an institution that supposedly treats mental problems, while actually worsens them. The novel exposes that through the operation of the reigning ideology, the inmates detained in the institution have turned into obedient, submissive "subjects" who have adjusted themselves to that ideology. The only inmate that resists the ideology and does not let the authorities turn him into another submissive "subject" is not supported by other inmates who paradoxically run him toward his destruction by urging him act as a hero that stands against the very ideology that rules over them, whereas they do not, or can not, support him. He is consequently punished by the system that ruthlessly turns him into an unconscious, lifeless piece of flesh by electric shock, and thereby slays his resisting spirit that defied their ideology. 


\section{References}

Althusser, L. (1971). Lenin and Philosophy and Other Essays. Trans. Ben Brewster. New York: Monthly Review.

--- (1990). Philosophy and the Spontaneous Philosophy of the Scientists, and other Essays. Ed. G. Elliott. Trans. B. Brewster et al. New York: Verso.

Bertens, H. (2001). Literary Theory: The Basics. London: Routledge.

Bloom, H., ed. (2007). Bloom's Critical Interpretation: Ken Kesey's One Flew over the Cuckoo's Nest. New York: Infobase Publishing.

Ferretter, L. (2007). Louis Althusser. Oxford: Routledge.

Ficks, T. H (1989). “The Hipster, the Hero, and the Psychic Frontier in One Flew over the Cuckoo's Nest”. Bloom $137-$ 150.

Hawkes, D. (2003). Ideology. London: Routledge.

Hicks, J. (1981). “The Truth Even If It Didn't Happen: One Flew over the Cuckoo's Nest”. Bloom 67-80.

Kesey, K. (1962). One Flew Over the Cuckoo's Nest. New York: New American Library.

Macherey, P. (2004). "For a Theory of literary Production”. Rivkin And Ryan 703-711.

Madden, F. (1986). “Sanity and Responsibility: Big Chief as Narrator and Executioner”. Bloom 107-121.

Martin, T. (1973). “One Flew over the Cuckoo's Nest and the High Cost of Living”. Bloom 3-14.

Rivkin, J., and Micheal R., eds. (2004). Literary Theory: An Anthology. $2^{\text {nd }}$ ed. Malden: Blackwell.

Selde, R., and Peter W.(1993). A Reader's Guide to Contemporary Literature Theory 3rd ed. Hertfordshire: Harvester WheatSheat.

Sullivan, R. (1975). “Big Mama, Big Papa, and Little Sons in Ken Kesey’s One Flew over the Cuckoo's Nest”. Bloom 15-28.

Tanner, S. L (1973). “The Western American Context of One Flew over the Cuckoo's Nest”. Bloom 161-185. 